УДК 633.854.78(477.61), DOI 10.31210/visnyk2018.04.03

(C) 2018

\author{
Маслійов С. В., доктор сільськогосподарських наук, \\ Шевченко А. М., доктор сільськогосподарських наук, \\ Степанов В. В., аспірант \\ (науковий керівник - доктор сільськогосподарських наук С. В. Маслійов) \\ Бугайов О. В., магістрант
}

Луганський національний університет ім. Тараса Шевченка

\title{
ВПЛИВ РІЗНИХ АГРОТЕХНІЧНИХ ПРИЙОМІВ НА ВИРОЩУВАННЯ ПІСЛЯУКІСНОГО СОНЯШНИКУ В УМОВАХ ЛУГАНСЬКОЇ ОБЛАСТІ
}

\section{Рецензент - доктор сільськогосподарських наук I. І. Ярчук}

\begin{abstract}
Проміжні культури є передусім важливим додатковим джерелом продукиії сільського господарства. Вони дають змогу в сівозмінах інтенсивного землеробства значно підвищити коефіиієнт використання ріллі (КВР), який характеризує відношення площі посівів сільськогосподарських культур до загальної площі ріллі. 3 розширенням проміжних культур КВР зростає від 1 до 1,3. Залежно від термінів посіву основних культур, після прибирання яких обробляються проміжні культури, вони діляться на озимину, пожнивну, підсівну і післяукісні.
\end{abstract}

Післяукісні проміжні культури висіваються після скошування основної озимини $і$ ярових культур на зелений корм. Вибір післяукісних культур визначається конкретними грунтово-кліматичними умовами $i$ господарськими потребами. У трунтово-кліматичних умовах півночі Луганської області з тирвалим теплим періодом зростання за достатньої вологозабеспеченності рослин в якості післяукісних культур використовуються кукурудза, гречка, просо, соя, соняиник та іниі.

У намій роботі виявлено відмінності під час особливостей вирошування соняшнику в післяукісному посіві після озимого жита, прибраного на зелену масу. Досліди проводилися на дослідних ділянках Луганського національного університету ім. Тараса Шевченка в 2015-2017 роках.

Після збирання озимого жита сіяли ранньостиглий гібрид соняшнику Pioneer P63LE113 по оранці $і$ поверхневій обробиі трунту на гербіцидному («Трефлан» 4-5 л/га, «Харнес» 2 кг/га) і безгербіцицному фонах. На обох способах посіву установлювали страхові надбавки 20, 40 і 60 \% до оптимальної переджнивної густоті стояння соняшнику на рядовому посіві 70 тис./га, иирокорядному - 50 тис./2а. Боронували соняшник бороною БЗСС-1,0, а на широкорядному посіві додатково за необхідності проводили міжрядні обробки. Найбільи високі урожаї забезпечуються під час посіву суцільним способом $i$ підтримці полів у чистому від бур'янів стані. При изьому виключаються міжрядні обробки.

Ключові слова: соняшник, післяукісні посіви, попередники, технологія вирощування, боронування, страхові надбавки, обробка трунту.
Постановка проблеми. Основною олійною культурою на Україні є соняшник. Площі його посівів становлять близько 2 млн га. Більше половини їх розміщують в степовій зоні. Вирощують соняшник в основному для отримання масла, якого в насінні міститься 48-54\%. Воно використовується в харчовій промисловості для виготовлення консервів, маргарину, кондитерських виробів, в хлібопекарському виробництві. Менш якісні сорти масла використовуються для виготовлення лаків, фарб, пластмас, оліфи і т.п.

Побічна продукція соняшнику $\epsilon$ хорошим кормом для тварин. Під час переробки насіння на масло виробляється 33-35 \% шроту (макухи), в якому міститься близько $40 \%$ протеїну, жири, вуглеводи, фосфатиди, фітин, вітаміни. Шрот широко використовується для виготовлення комбікормів, а білок соняшнику знаходить усе більше використання в харчовій промисловості. Під час переробки насіння отримують в якості відходу лушпиння, яке $\epsilon$ цінною сировиною для вироблення фурфуролу, спирту, кормових дріжджів $[4,8]$.

Проте площі післяукісного соняшнику на насіння в Степу України поки що незначні, що $\epsilon$ наслідком недостатніх знань про можливість таких посівів і недостатньої вивченості агротехніки вирощування.

Аналіз останніх досліджень і публікацій, у яких започтаковано розв'язання проблеми. У літературі з цього питання відомостей мало. До початку наших досліджень в післяукісних і пожнивних посівах соняшник вивчали у більшості випадків на зрошуваних землях півдня України, де більш тривалий i теплий вегетаційний період. В Степу України досліджуванням цієї проблеми займалися І. Д. Ткаліч та А. А. Демідов [7]. В Луганській області таких досліджень майже не проводили. Не було також наукового обгрунтування можливостей других посівів на незрошуваних землях. 


\section{СІЛЬСЬКЕ ГОСПОДАРСТВО. РОСЛИННИЦТВО}

Важливим вбачається вивчення закономірностей формування рослин соняшнику під сукупним впливом прийомів, що вивчалися, використання вологи, ФАР, виживаності соняшнику, продуктивності [6].

На основі отримуваних даних важливо було встановити оптимальні показники кожного чинника за комплексної дії прийомів, оскільки оптимальні їх показники визначають повноту використання грунтово-кліматичних ресурсів зони для отримання високих урожаїв.

Головною метою роботи було вивчити ріст, розвиток і продуктивність післяукісного соняшнику залежно від способів розміщення рослин на площі, страхових надбавок і норм висіву, боронувань по оранці і поверхневій обробці на гербіцидному i безгербіцидному фонах, встановити можливість підвищення врожайності і зниження витрат за рахунок оптимізації агротехнічних прийомів.

Завдання досліджень - визначити можливість вирощування соняшника в післяукісних посівах після озимого жита. Визначити зміни урожайності залежно від способів розміщення рослин на площі, страхових надбавок і норм висіву, боронувань по оранці і поверхневій обробці на гербіцидному і безгербіцидному фонах.

Матеріали і методи дослідження. Експериментальну роботу проводили в 2015-2017 роках на кафедрі біології Луганського національного університету імені Тараса Шевченка та на землях Старобільського дослідного господарства ЛНУ імені Тараса Шевченка, розташованого в північноцентральній помірно посушливій підзоні Степової північної зони.

Грунти дослідних ділянок - чорноземи звичайні на лесових породах із товщиною гумусового шару 65-80 см. Вміст гумусу в орному шарі грунту (за Тюріним) - 3,8-4,2 \%, валового азоту - 0,21-0,26\%, легкогідролізованого азоту (за Корнфілдом) - 105-150 мг/кг грунту, рухомого фосфору - 84-115 мг/кг і обмінного калію (за Чиріковим) - 81-120 мг/кг грунту. Реакція грунтового розчину була нейтральною або слаболужною. Об' ємна маса шару грунту 0-30 см - 1,30-

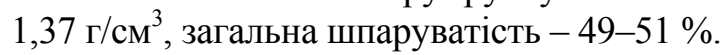

Сума поглинених катіонів досягала 49-54 мгекв. на 100 г грунту. Серед поглинених катіонів $\mathrm{Ca}$ i $\mathrm{Mg}$ займали 95-99 \% зі співвідношенням між ними 8-9:1. Реакція грунтового розчину була нейтральною або слаболужною.

Найменша вологоємність метрового шару грунту сягала 24-28\% (357-399 мм), вологість стійкого в'янення рослин - 12-16 \% (202-218 мм). Об'ємна

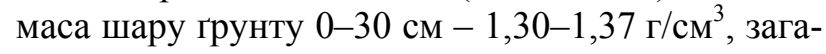

льна шпаруватість - 49-51\%.

За особливостями рельєфу і грунтового покриву дослідні ділянки були характерними для північно-центральної помірно посушливої підзони Степової північної зони і відрізнялися відносно високою родючістю і сприятливими умовами [5].

За рівнем агрокліматичних факторів територію проведення польових дослідів відносять до північного теплого і посушливого агрокліматичного району, головною особливістю якого є різка континетальність 3 чітко вираженою сезонною контрастністю показників погодно-кліматичних елементів.

Досліди 3 післяукісним соняшником проводили в ланці сівозміни: озима пшениця - кукурудза на силос - озиме жито на зелений корм + напіввідсталий соняшник. Повертали соняшник на колишне місце через 6 років. Озиме жито на зелений корм вирощували згідно 3 рекомендаціями для степової зони України $[1,3]$. Сіяли зерновою сівалкою «С $3-3,6 »$ по поверхневій обробці після кукурудзи, прибраної на силос, поле дискували важкою бороною БДТ-7, одночасно культивували і сіяли 3 нормою висіву 4,5 млн зерен на гектар.

Прибирання озимого жита на зелений корм проводили на початку колосіння 16 травня. На поле, що звільнилося від озимого жита, вносили мінеральні добрива у вигляді аміачної селітри i суперфосфату 3 розрахунку $\mathrm{N}_{40} \mathrm{P}_{60}$ і негайно його закладали в грунт носовими боронами БДТ-7 на глибину 8-10 см. Одночасно при цьому проводилось і лущення.

Потім, згідно зі схемою досвіду, частину ділянки орали на глибину 20-22 см кутом ПЛН-5-35 3 катком 3ККШ-6, на іншій частині залишалася поверхнева обробка. Після дискування грунт культивували перед сівбою КПС-4.

Досліди проводили на гербіцидному і безгербіцидному фонах. Для цього на половині площі ділянок обприскувачем ОП-2000 вносили гербіцид «Трефлан» 3 розрахунку 5 л/га. Цей гербіцид леткий, тому його закладали в грунт під час передпосівної культивації. На іншому варіанті досліду застосували технологічний гербіцид «Харнес» (2 л/га). Широкорядну сівбу соняшнику проводили сівалкою «СУПН-8», а звичайну рядову - за допомогою сівалки «С3-3,6», з дотриманням страхових добавок 20, 40 і $60 \%$ до оптимальної густини, встановленої раніше І.Д. Ткалічем, А. А. Демідовим [7] для пунктирної широкорядної сівби 50 тис./га, а звичайної рядової - 70 тис./га. Після сівби поле боронували (БЗСС-1,0) і накочували (ЗККШ-6). 


\section{СІЛЬСЬКЕ ГОСПОДАРСТВО. РОСЛИННИЦТВО}

Це забезпечило вирівнювання і ущільнення грунту, що поліпшило контакт насіння 3 грунтом, зменшило непродуктивний випар вологи i сприяло отриманню повноцінних сходів соняшнику.

Догляд за посівами складався 3 боронувань i міжрядних обробок. Боронування проводили бороною БЗСС-1,0 по усіх фонах і способах сівби.

На першому варіанті проводили тільки післяпосівне боронування.

На другому окрім нього провели ще одне, під час сходів соняшнику у фазу сім'ядоль.

На третьому варіанті боронували після сівби $\mathrm{i}$ в разі появи «ниточок» або сходів бур'янів на поверхні грунту в період від однієї до трьох пар листків у соняшника. Тут на рядовому і широкорядному посівах на ділянках без гербіцидів провели два післясходових боронування, у фазі 1-2 пар листків у соняшнику. Це було необхідно чеpeз гарну вологозабеченість грунту і підвищену засміченість посівів.

На гербіцидному фоні провели одне боронування у фазі 1-3 пар листків соняшника.

Проведення дослідів та обробка отриманих результатів проводилися згідно 3 методикою польового досліду Доспєхова [2].

Результати досліджень. На польову схожість істотний вплив мали обробка грунту і густина посіву, обумовлена страховими добавками. У зв'язку з рихлішим складом грунту по оранці сівалкою «С3-3,6» дисковими сошниками вдалося глибше і більш рівномірно закласти насіння в грунт, тому під час сівби 3 міжряддями 15 см за усіх страхових добавках кількість рослин, що зійшли, у більшості була вища на 0,8-11,3\%, ніж за поверхневої обробки, де диск стрибав по нерівностях і пожнивних залишках, а грунт швидше пересихав на глибину обробки і багато насіння залишалися у сухому шарі грунту.

У випадку сівби сівалкою «СУПН-8» цих відмінностей були менше $(0,2-7,7 \%)$, оскільки за допомогою робочих органів сівалки вдавалося уникнути вказаних недоліків і в чотирьох випадках 3 дев'яти схожість насіння по поверхневій обробці була вища, ніж по оранці, на 1,9-2,3%.

Істотних відмінностей щодо схожості насіння між широкорядним і рядовим посівом за страхової добавки 20 \% практично не було. Проте по оранці в разі страхової добавки 40-60 \% і поверхневій обробці за $60 \%$ польова схожість була вища, ніж на широкорядному посіві, на 1-5,3 \%.

Це явище можна пояснити зниженням конкуренції між проростками за поживні елементи i вологу в рядовому посіві, де насіння більш рівномірно розміщується на площі, чим в широкорядному.

Зниження повноти сходів у випадку загущення посівів із підвищенням страхової добавки насіння також, мабуть, пов'язано зі збільшенням конкуренції між проростками.

Зміна термінів настання основних фаз росту i розвитку соняшника залежать не лише від погодних умов, групи стиглості, але й агротехнічних прийомів, серед яких істотне місце займають обробка грунту, густина і прийоми догляду за посівами.

\section{1. Вплив способів обробки трунту, сівби та страхових добавок до норми висіву на тривалість міжжфазних періодів соняшника під час проведення 2-3 боронувань на безгербіцидному фоні (середні показники за 2015-2017 роки)}

\begin{tabular}{|c|c|c|c|c|c|c|c|}
\hline $\begin{array}{c}\text { Способи } \\
\text { обробки } \\
\text { грунту }\end{array}$ & $\begin{array}{l}\text { Ширина } \\
\text { міжрядь }\end{array}$ & $\begin{array}{c}\text { Страхові } \\
\text { надбавки, } \\
\%\end{array}$ & $\begin{array}{c}\text { Сходи - } \\
\text { утворення } \\
\text { корзинки }\end{array}$ & $\begin{array}{c}\text { Утворення } \\
\text { корзинки - } \\
\text { цвітіння }\end{array}$ & $\begin{array}{c}\text { Цвітіння } \\
\text { - дозрі- } \\
\text { вання }\end{array}$ & $\begin{array}{c}\text { Сходи - } \\
\text { повна } \\
\text { стиглість }\end{array}$ & $\begin{array}{c}\text { Cе- } \\
\text { ред- } \\
\text { нє }\end{array}$ \\
\hline \multirow{6}{*}{$\begin{array}{c}\text { Оранка на } \\
20-22 \text { см }\end{array}$} & \multirow{3}{*}{70} & 20 & 45 & 25 & 65 & 135 & 130 \\
\hline & & 40 & 45 & 25 & 65 & 135 & 130 \\
\hline & & 60 & 45 & 25 & 63 & 133 & 126 \\
\hline & \multirow{3}{*}{15} & 20 & 46 & 24 & 62 & 132 & 126 \\
\hline & & 40 & 46 & 24 & 62 & 132 & 125 \\
\hline & & 60 & 46 & 24 & 61 & 131 & 124 \\
\hline \multirow{6}{*}{$\begin{array}{c}\text { Поверхнева } \\
\text { обробка }\end{array}$} & \multirow{3}{*}{70} & 20 & 45 & 25 & 65 & 135 & 130 \\
\hline & & 40 & 45 & 25 & 65 & 135 & 130 \\
\hline & & 60 & 45 & 25 & 63 & 133 & 127 \\
\hline & \multirow{3}{*}{15} & 20 & 45 & 24 & 62 & 131 & 125 \\
\hline & & 40 & 45 & 24 & 62 & 131 & 125 \\
\hline & & 60 & 45 & 24 & 61 & 130 & 123 \\
\hline
\end{tabular}




\section{СІЛЬСЬКЕ ГОСПОДАРСТВО. РОСЛИННИЦТВО}

У розріджених посівах зазвичай рослини соняшнику зацвітають раніше, ніж за оптимальної густини, а дозрівають на 4-3 дні пізніше. У значно загущених посівах тривалість вегетації скорочується. Скороченню вегетаційного періоду соняшнику до 4-х днів сприяє і звуження міжрядь.

Скорочення тривалості вегетаційного періоду відбувалося в основному за рахунок зменшення періоду від цвітіння до повної стиглості, тобто прискорення дозрівання насіння. Проте цей період все-таки був тривалішим, чим зазвичай під час весняної сівби, оскільки терміни дозрівання відтягувалися на більш пізній час, коли настають знижені температури і вища вологість повітря. Період від сівби до сходів склав 5-7 днів, від сходів до утворення кошиків - 39, від утворення кошиків до цвітіння - 20, від цвітіння до повного дозрівання насіння - 68 днів (табл. 1). Таким чином, в умовах північної підзони Степу України в разі сівби ранньостиглого гібриду соняшнику Pioneer P63LE113 6-16 червня після прибирання озимого жита на зелений корм соняшник дозріває в другий - на початку третьої декади жовтня. Тривалість вегетаційного періоду - 123-130 днів. В окремі роки він потрапляє під заморозки, що призводить до ушкодження тканин рослин, їх швидкого висихання. Це сприяє прискоренню дозрівання і отриманню повноцінного урожаю. У випадку звуження міжрядь з 70 до 15 см і збільшення густини стояння рослин за допомогою підвищення страхової надбавки з 20 до 60 \% тривалість вегетаційного періоду скорочується на 25 днів, що є позитивним чинником, оскільки рослини рятуються від пізніших понижених температур і захворювань гнилизною. Вплив обробок грунту, гербіцидів і боронувань посівів на терміни проходження фаз росту i розвитку рослин соняшнику не виявлено.
Також встановлено, що розміри асиміляційного апарату рослин, тривалість його життєдіяльності i продуктивність фотосинтезу листя визначають врожайність сільськогосподарських культур. Між тим величину листкової поверхні й інтенсивність фотосинтетичних процесів значною мірою визначають спосіб сівби, густота, обробка грунту, від яких залежить площа живлення рослин, інтенсивність освітлення, вологозабезпесченість.

Дані, отримані нами, свідчать, що на освітленість усередині посіву, поглинання сонячної радіації і продуктивність листя впливають не лише їх площа, але і розміщення рослин, густина стеблестою, обумовлена способами сівби і боронуванням. Тому у зв'язку з більшою густиною стояння рослин і великим листковим індексом в суцільних посівах спостерігається менша інтенсивність освітлення листя, але більший відсоток (62,0-65,7 \%) поглиненої сонячної радіації (табл. 2). Найбільше сонячної радіації поглиналося звичайними рядовими посівами за посходових боронувань, де формувалася велика площа листя i рослини рівномерніше, ніж на широкорядному посіві, розміщувалися на площі. Безумовно, збільшення поглинання радіації посівами 3 більшою площею листя сприяє виконанню більшої суми фотосинтетичної роботи і отриманню вищих урожаїв. Проте з підвищенням площі асимілюючої поверхні погіршується освітлення листя середніх і нижніх ярусів і знижується продуктивність їх роботи. Так, у наших дослідах за листкового індексу 2,31-2,64 $\mathrm{m}^{2} / \mathrm{M}^{2}$ по оранці і 2,17$2,50 \mathrm{~m}^{2} / \mathrm{M}^{2}$ по поверхневій обробці на звичайному рядовому посіві освітленість становила, відповідно, 24,6-26,0 \% і 25,5-27,6 \% від тієї, що надходить, а на широкорядному - 30,0-32,8 \% i $32,7-33,2 \%$.

\section{2. Фотосинтетичні показники післяукісного соняшника в залежності від обробки грунту, способу сівби та боронувань (середні показники за 2015-2017 роки)}

\begin{tabular}{|c|c|c|c|c|c|c|}
\hline $\begin{array}{c}\text { Обробка } \\
\text { груту }\end{array}$ & $\begin{array}{c}\text { Способи } \\
\text { сівби }\end{array}$ & $\begin{array}{c}\text { Кількість } \\
\text { боронувань }\end{array}$ & $\begin{array}{c}\text { Листковий } \\
\text { індекс, } \text { м }^{2} / \mathrm{M}^{2}\end{array}$ & $\begin{array}{c}\text { Освітлення, } \\
\text { \% від тієї, } \\
\text { що } \\
\text { надходить }\end{array}$ & $\begin{array}{c}\text { Поглинена } \\
\text { ФАР, \% від } \\
\text { тієї, що } \\
\text { надходить }\end{array}$ & 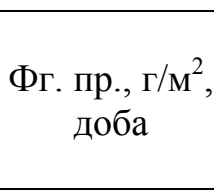 \\
\hline \multirow{4}{*}{$\begin{array}{l}\text { Поверх- } \\
\text { нева }\end{array}$} & \multirow{2}{*}{$\begin{array}{l}\text { Широко- } \\
\text { рядний }\end{array}$} & 0 & 2,17 & 33,2 & 56,6 & 8,7 \\
\hline & & $1-3$ & 2,30 & 32,7 & 57,5 & 8,9 \\
\hline & \multirow{2}{*}{$\begin{array}{l}\text { Звичайний } \\
\text { рядковий }\end{array}$} & 0 & 2,33 & 27,6 & 62,9 & 8,0 \\
\hline & & $1-3$ & 2,50 & 25,2 & 64,5 & 8,3 \\
\hline \multirow{4}{*}{ Оранка } & \multirow{2}{*}{$\begin{array}{l}\text { Широко- } \\
\text { рядний }\end{array}$} & 0 & 2,31 & 32,8 & 57,6 & 8,9 \\
\hline & & $1-3$ & 2,41 & 30,0 & 58,6 & 9,3 \\
\hline & \multirow{2}{*}{$\begin{array}{l}\text { Звичайний } \\
\text { рядковий }\end{array}$} & 0 & 2,49 & 26,0 & 64,4 & 8,2 \\
\hline & & $1-3$ & 2,64 & 24,6 & 65,7 & 8,4 \\
\hline
\end{tabular}




\section{СІЛЬСЬКЕ ГОСПОДАРСТВО. РОСЛИННИЦТВО}

Вплив боронувань на освітленість в посіві був невеликим. Простежувалася тенденція до зниження освітленості на 1,4-2,8 \% на боронованих по сходах ділянках через збільшення індексу листкової поверхні. На варіантах без боронування посіви були більше загущеними, ріст листя йшов гірше і воно всихало раніше і сильніше, що зменшило площу листя i призвело до підвищення освітленості. Чиста продуктивність фотосинтезу не зростала, але все ж була вищою на 0,2-0,4 $\Gamma / \mathrm{M}^{2}$ не на цих варіантах, а по боронуванню, де рослини менше страждали від посухи.

Висновок. На широкорядному посіві провели дві обробки міжрядь. Врожайність отримали на широкорядному 11,3 , а на суцільному - 14,2 ц/га. У 2017 р. вивчали ефективність оранки і поверхневої обробки за сівби суцільним рядовим способом на безгербіцидному і гербіцидному фонах. Площа ділянок склала по 3 га. Врожайність насіння отримали за широкорядної сівби по оранці 18,0 і 18,9 ц/га, по поверхневій обробці - 16,3 i 17,6 ц/га (відповідно, по безгербіцидному і гербіцидному фонам) у разі суцільного посіву $-16,1$ i 21,2 ц/га. Технологія обробітку соняшнику за сівби 3 міжряддями 15 см впроваджена в 2016 р. на площі 30 га, в 2017 г. - на 28 га. Врожайність насіння соняшнику отримали 14,2 і 21,2 ц/га (табл. 3).
Ефективність гербіцидів за дією на врожайність вище, ніж боронувань. Проведення досходового боронування менше очищувало грунт від бур'янів, ніж 2-3 післясходових, особливо у фазі «ниточки» і появи бур'янів на поверхні грунту, тому найвища врожайність формувалася на ділянках, де проводили досходовое і 1-3 післясходових боронувань. Так, у середньому за роки досліджень врожайність соняшнику в разі проведення декількох боронувань по поверхневій обробці склала на безгербіцидному фоні 13,5 ц/га, гербіцидному - 14,2 ц/га, а тільки досходового - 12,4 і 14 ц/га. По оранці врожайність була, відповідно, 14,9, 15,1 і 14,0, 14,6 ц/га. Боронування на фоні гербіцидів менш ефективне, ніж без них. У першому випадку надбавка врожаю склала $0,2-0,5$ ц/га $(1,4-3,4 \%)$, у другому - 0,9$1,1 ц / г а(6,4-8,9 \%)$.

Знижується ефективність боронувань і за сівби широкорядним способом у порівнянні 3 суцільним. Це пов'язано, можливо, з тим, що на широкорядних посівах проводяться додатково міжрядні обробки. Так, у середньому надбавка врожаю від проведення боронувань після сходів на суцільному посіві склала 0,9 ц/га, а на широкорядному - в два рази менше $(0,5$ ц/га).

\section{3. Вплив агротехнічних прийомів на врожайність післяукісного сонячника, и/га (середні показники за 2015-2017 роки)}

\begin{tabular}{|c|c|c|c|c|c|c|c|}
\hline \multirow[b]{3}{*}{$\begin{array}{c}\text { Способи } \\
\text { сівби }\end{array}$} & \multirow[b]{3}{*}{$\begin{array}{c}\text { Страхова } \\
\text { надбавка, } \\
\%\end{array}$} & \multicolumn{6}{|c|}{ Строки боронувань } \\
\hline & & \multicolumn{3}{|c|}{ По поверхневій обробці } & \multicolumn{3}{|c|}{ По оранці } \\
\hline & & $\begin{array}{c}\text { Після } \\
\text { сівби }\end{array}$ & $\begin{array}{c}\text { Посля сівби } \\
\text { та під час } \\
\text { сходів }\end{array}$ & $\begin{array}{c}\text { У випа- } \\
\text { дку } \\
\text { появи } \\
\text { бур'янів }\end{array}$ & $\begin{array}{l}\text { Після } \\
\text { сівби }\end{array}$ & $\begin{array}{l}\text { Посля сівби } \\
\text { та підчас } \\
\text { сходів }\end{array}$ & $\begin{array}{c}\text { У випа- } \\
\text { дку } \\
\text { появи } \\
\text { бур'янів }\end{array}$ \\
\hline \multicolumn{8}{|c|}{ Без гербіцидів } \\
\hline \multirow{3}{*}{$\begin{array}{c}\text { Звичайний } \\
\text { рядковий }\end{array}$} & 20 & 12,8 & 13,5 & 13,6 & 15,0 & 14,1 & 15,1 \\
\hline & 40 & 12,6 & 13,6 & 14,2 & 14,7 & 14,2 & 15,5 \\
\hline & 60 & 12,6 & 13,6 & 14,4 & 14,5 & 14,4 & 16,5 \\
\hline \multirow{3}{*}{$\begin{array}{l}\text { Широко- } \\
\text { рядний }\end{array}$} & 20 & 12,5 & 12,7 & 12,7 & 13,7 & 13,4 & 14,1 \\
\hline & 40 & 12,2 & 12,4 & 12,9 & 13,4 & 12,9 & 14,3 \\
\hline & 60 & 11,9 & 12,4 & 13,0 & 12,5 & 12,8 & 13,9 \\
\hline \multicolumn{8}{|c|}{ На фоні грунтового гербіциду } \\
\hline \multirow{3}{*}{$\begin{array}{c}\text { Звичайний } \\
\text { рядковий }\end{array}$} & 20 & 15,0 & 14,2 & 14,6 & 15,3 & 15,1 & 14,9 \\
\hline & 40 & 15,5 & 15,5 & 16,1 & 16,8 & 16,2 & 16,7 \\
\hline & 60 & 13,9 & 14,6 & 15,0 & 14,5 & 15,8 & 17,2 \\
\hline \multirow{3}{*}{$\begin{array}{l}\text { Широко- } \\
\text { рядний }\end{array}$} & 20 & 12,9 & 12,2 & 12,7 & 14,0 & 12,9 & 13,8 \\
\hline & 40 & 13,4 & 13,4 & 13,6 & 13,6 & 14,0 & 14,2 \\
\hline & 60 & 13,0 & 13,0 & 13,4 & 13,3 & 13,2 & 14,0 \\
\hline
\end{tabular}


Таким чином, дослідження показали, що в післяукісних посівах соняшник можна сіяти широкорядним і звичайним рядковим способом. Найбільш високі урожаї забезпечуються за сівби суцільним способом і підтримці полів у чистому від бур'янів стані. При цьому виключаються міжрядні обробки. Найвищий ефект у боротьбі зі смітною рослинністю дає застосування грунто-

\section{БІБЛІОГРАФІЯ}

1. Валитов $A$ B. Формирование агроценозов кормовых культур в промежуточных посевах / А. В. Валитов - Вестник БГАУ, № 3, 2011. - С. 12-20

2. Доспехов Б. А. Методика полевого опыта (с основами статистической обработки результатов исследований) / Б. А. Доспехов. - М. : Агропромиздат, 1985. - 351 с.

3. Киреев. В. М. Кормовые культуры в промежуточных посевах / В. М. Киреев, В. Д. Клинов - Степные просторы, № 4, 1986. - С. 38-39.

4. Кононюк. В. Соняшник - провідна культура АПК України / В. Кононюк. - Агровісник Україна, № 1, 2007. - 50 c.

\section{ANNOTATION}

Masliiov S. V., Shevchenko A. M., Stepanov V.V., Buhaiov O.V. Influence of different agricultural approvals on growing of post sucrose sunglass in conditions of Luhansk region.

Intermediate crops are primarily an important additional source of agricultural production. They allow crop rotation of intensive agriculture to significantly increase utilization rate of arable land (UR of AL), which characterizes the ratio of the area of crops to the total area of arable land. With the expansion of intermediate crops, the $\mathrm{UR}$ of $\mathrm{AL}$ increases from 1 to 1.3. Depending on the dates of sowing of the main crops, after harvesting of which intermediate crops are cultivated, they are divided into wintering, sowing and post-skeletal.

Post-skeletal intermediate crops are sown after cutting the main winter crops and spring crops on green feed. The choice of post-ear crops is determined by specific soil-climatic conditions and household needs. In soil-climatic conditions in the north of Luhansk region with a thriving warm period of growth with sufficient moisture supply of plants, post-crop crops use corn, buckwheat, millet, soya, sunflower, and others. вих гербіцидів («Трефлан» 4-5 л/га, «Харнес» 2 л/га). За відсутності гербіцидів гарні результати у боротьбі з бур'янами забезпечують боронування БЗСС-1,0 по сходах соняшнику у фазі «ниточки» бур'янів або їх проростання. У роки 3 гарною вологозабезпеченістю вищі урожаї соняшнику дає оранка, ніж поверхнева обробка.

5. Маслійов. С. В. Вплив біопрепаратів на харчові підвиди кукурудзи (монографія) / С. В. Маслійов, Н. Ю. Мацай, Є. С. Маслійов ДЗ «ЛНУ імені Тараса Шевченка», 2018. - 163 с.

6. Посыпанов Г. С. Растениеводство / Г. С. Посыпанов. - М. : Колос, 2006. -612 с.

7. Ткалич И. Д. Поукосные посевы / И. Д. Ткалич, Н. 3. Дидык, А. А. Демидов. - Днепропетровск: Бюл. Института кукурузы, Вып. 80, 1992. - С. 115120.

8. Троценко B. I. Соняшник: селекція, насінництво, технологія вирощування (монографія) / В. I. Троценко. - Суми : Видавництво «Університетська книга», 2001. - 184 с.

Our work revealed differences in the peculiarities of growing sunflower in post-crop sowing after winter rye, harvested on green mass. Experiments were conducted on experimental sites of Luhansk National University of Taras Shevchenko in 20152017. After harvesting of winter rye, an earlyseeded hybrid of Pioneer P63LE113 sunflower was sown by rooting and surface treatment of the soil on herbicide (Treflan 4-5 1/ha, Harnes $2 \mathrm{~kg} / \mathrm{ha}$ ) and non-herbicide backgrounds.

On both methods of sowing, insurance premiums were set at 20,40 and $60 \%$ to the optimal density of sunflower stand on ordinary crops of $70 \mathrm{th} / \mathrm{ha}$, and broad-row - 50 th/ha. Flours of sunflower with harrow BZSS - 1.0, but on wide-range crop additional, if necessary, inter-row processing. The highest yields are provided when sown in a continuous manner and the maintenance of fields in a pure state of weeds. It eliminates inter-row processing.

Key words: sunflower, post-harvest crops, precursors, technology of cultivation, harrowing, insurance premiums, soil cultivation. 